\title{
EFEK ESTROGENIK EKSTRAK BUAH TOMAT (lycopersicum esculentum) TERHADAP MENCIT BETINA DEWASA (Mus musculus) GALUR BALB/C
}

\section{ESTROGENIC EFFECT OF TOMATO FRUIT EXTRCAT (Lycopersicum esculentum) OF ADULT FEMALE MICE (Mus musculus) BALB/C STRAIN}

\author{
Syamsul Bahri ${ }^{1 *}$, Irmayani², Jami'atul Aulia², Miqro' Fajari Lathifah' ${ }^{2}$ dan Rabiatul Adawiyah ${ }^{2}$ \\ ${ }^{1}$ Program Studi Pendidikan Biologi FKIP, Universitas Mataram, Mataram, Indonesia \\ ${ }^{1,2}$ Program Studi Magister Pendidikan IPA Universitas Mataram, Mataram, Indonesia \\ *Email: syamsulsalihu@yahoo.co.id
}

Diterima: 21 Januari 2021. Disetujui: 8 Februari 2021. Dipublikasikan: 3 Maret 2021

\begin{abstract}
Abstrak: Tujuan dari penelitian ini adalah untuk mengetahui pengaruh estrogenik ekstrak buah tomat (Lycopersicum esculentum) terhadap mencit betina dewasa (Mus musculus) galur Balb/C. Penelitian ini menggunakan Rancangan Acak Lengkap (RAL) yang terdiri dari empat kelompok perlakuan dengan masingmasing enam ulangan. Perlakuan P1 sebagai kontrol diberi aquades dan perlakuan P2, P3 dan P4 diberi ekstrak buah tomat dengan dosis $100 \mathrm{mg} / \mathrm{KgBB}, 150 \mathrm{mg} / \mathrm{KgBB}$ dan $200 \mathrm{mg} / \mathrm{KgBB}$. Ekstrak buah tomat diberikan setiap hari secara oral selama tiga hari dengan metode gavage. Hasil penelitian menujukkan bahwa pemberian ekstrak tomat (Lycopersicum esculentum) dapat meningkatkan siklus estrus pada mencit betina galur Balb/C. Pemberian ekstrak tomat dosis 100, 150 dan $200 \mathrm{mg} / \mathrm{Kg}$ BB mencit/hari menujukkan peningkatan siklus estrus selama 1 hari dibandingkan dengan kelompok kontrol tanpa pemberian ekstrak buah tomat (Lycopersicum esculentum). Hal ini dapat dilihat dari data yang menunjukkan bahwa pada kelompok kontrol, siklus estrus berlangsung selama 4 hari. Selanjutnya pada kelompok perlakuan 1, perlakuan 2, dan perlakuan 3 siklus estrus berlangsung selama 5 hari.
\end{abstract}

Kata Kunci: Lycopersicum esculentum, Efek Estrogenik, Mus musculus galur Balb/C

\begin{abstract}
The purpose of this study was to determine the estrogenic effect of tomato fruit extract (Lycopersicum esculentum) on adult female mice (Mus musculus) Balb / C strain. This study used a completely randomized design (CRD) consisting of four treatment groups with six replications each. P1 treatment as a control was given distilled water and P2, P3 and P4 treatments were given tomato fruit extract at doses of $100 \mathrm{mg} / \mathrm{KgBB}, 150 \mathrm{mg} / \mathrm{KgBB}$ and $200 \mathrm{mg} / \mathrm{KgBB}$. Tomato fruit extract was given orally for three days using the gavage method. The results showed that administration of tomato extract (Lycopersicum esculentum) could increase the estrous cycle in female Balb / C mice. The administration of tomato extract at a dose of 100, 150 and $200 \mathrm{mg} / \mathrm{Kg} \mathrm{BW} /$ day showed an increase in the estrous cycle for 1 day compared to the control group without giving tomato fruit extract (Lycopersicum esculentum). This can be seen from the data which shows that in the control group, the estrous cycle lasts for 4 days. Furthermore, in treatment group 1, treatment 2, and treatment 3 cycles of estrus lasted 5 days.
\end{abstract}

Keywords: Lycopersicum esculentum, Estrogenic Effects, Mus musculus Balb/C strain

\section{PENDAHULUAN}

Reproduksi

adalah proses perkembangbiakan suatu makhluk hidup. Siklus reproduksi normal melingkupi penyertaan dan penyesuaian banyak mekanisme fisiologik baik dari dalam maupun dari luar tubuh. Siklus reproduksi pada hewan betina dewasa dikenal dengan istilah siklus estrus [8]. Siklus estrus merupakan suatu fase dari terjadinya estrus ke estrus berikutnya dan meliputi perubahan-perubahan siklik pada organorgan reproduksi tertentu, seperti ovarium, uterus, dan vagina dibawah pengendalian berbagai hormonhormon reproduksi, termasuk hormon estrogen [10]

Hormon estrogen merupakan hormon reproduksi yang berperan penting dalam sistem reproduksi hewan betina. Estrogen dapat menambah sintesis dan ekskresi hormon pertumbuhan sehingga dapat menstimulir pertumbuhan sel-sel dalam tubuh
[21]. Estrogen juga dapat menimbulkan efek estrogenik terhadap aktivitas betina seperti perkembangan sifat seksual sekunder, perilaku persiapan kawin atau estrus, mempersiapkan uterus untuk implantasi dan menyiapkan perkembangan kelenjar susu. Aktifitas estrogenik juga dimiliki oleh fitoestrogen yang merupakan senyawa alami dari beberapa tumbuhan [16].

Fitoestrogen adalah zat turunan tanaman yang secara struktural dan secara fungsional mirip estrogen. Adanya gugus hidroksil $\mathrm{OH}$ pada fitoestrogen merupakan salah satu persyaratan untuk aktivitas estrogenik yang akan berikatan dengan reseptor estrogen [11]. Fitoestrogen mampu menjadi pendukung jika keberadaan estrogen endogen tubuh sedikit atau berkurang melalui ikatan dengan reseptor estrogen yang masih kosong. Pada sitoplasma, fitoestrogen berikatan dengan reseptor estrogen 
sehingga menghasilkan kompleks hormon reseptor yang aktif [2]. Fitoestrogen dapat ditemukan pada kelompok tanaman termasuk biji-bijian, kacangkacangan, sayuran dan buah-buahan, salah satunya pada buah tomat [26].

Tomat (Lycopersicum esculentum) merupakan salah satu sayuran yang kaya akan senyawa antioksidan seperti vitamin $\mathrm{E}$, vitamin $\mathrm{C}$, karotenoid, dan likopen yang penting untuk kesehatan [24]. Buah tomat biasanya dapat dikonsumsi langsung atau menjadi makanan dan minuman olahan. Buah tomat selain sebagai sayuran juga banyak dimanfaatkan masyarakat untuk mengobati beberapa penyakit seperti antiradang, hipertensi, jantung koroner, anti kanker [29] Berdasarkan penelitian terdaulu melaporkan senyawa dalam buah tomat efektif untuk meningkatkan ketebalan epitel dinding vagina karena mengandung fitoestrogen yang tinggi [15].

Salah satu senyawa utama yang terdapat di dalam buah tomat adalah likopen [30]. Likopen merupakan zat pigmen golongan karotenoid yang menyebabkan warna merah pada buah tomat. Senyawa ini diketahui dapat mengurangi resiko penyakit hipertensi, aterosklerosis, penyakit kardiovaskular, gangguan neurodegenerative, dan kanker terutama kanker prostat [13], [4]. Beberapa studi literatur juga menyebutkan bahwa likopen memiliki efek estrogenik [22] seperti dapat memperbaiki fungsi sel reproduksi, [23], menjaga kualitas sel sperma [27], serta dapat meningkatkan ketebalan dinding vagina [26]

Penelitian ini bertujuan untuk mengetahui efek estrogenik ekstrak buah tomat (Lycopersicum esculentum) mencit betina dewasa (Mus musculus) galur Balb/C.

\section{METODE PENELITIAN Waktu dan Tempat Penelitian}

Penelitian ini dilakukan di Laboratorium FKIP Universitas Mataram pada bulan Oktober sampai dengan bulan November 2020.

\section{Alat dan Bahan Penelitian}

Alat dan bahan yang di gunakan dalam penelitian ini terdiri dari kandang mencit, neraca analitik, botol minumam berpipet, cutton bud, siring, sarung tangan, kaca benda, kaca penutup, pipet tetes, gelas kimia, dan mikroskop. Bahan yang digunakan terdiri atas: ekstrak tomat, mencit, sekam, $\mathrm{NaCl}$ $0,9 \%$, pewarnaan methylene blue.

\section{Persiapan Hewan Coba}

Hewan coba yang digunakan dalam penelitian ini berupa mencit betina dewasa ( $M$. musculus) umur 8 bulan dengan berat badan rata-rata 23 gram dengan jumlah 24 ekor. Hewan ini diaklimasi di dalam Laboratorium FKIP Universitas Mataram. Hewan coba dibagi ke dalam empat kelompok perlakuan yang masing-masing terdiri atas enam ekor mencit betina

\section{Pembuatan Eksrak Buah Tomat (Lycopersicum esculentum)}

Penelitian yang telah dilakukan melalui beberapa tahap, tahap pertama adalah pembuatan ekstrak buah tomat dengan tekhnik maserasi. Tomat dipisahkan antara daging buahnya dan bijinya. Daging buah tomat dipotong kecil-kecil kemudian dikeringkan pada suhu ruangan selama 72 jam. Setelah kering daging buah tomat diblender untuk menjadikannya menjadi serbuk. Serbuk daging buah tomat kemudian diekstraksi dengan metode maserasi menggunakan pelarut etanol 96\%. Sebanyak 200 gram tomat direndam dengan 1 Liter etanol selama 72 jam dengan sesekali dilakukan pengadukan. Hasil rendaman kemudian disaring untuk memisahkan residu dan filtrat. Filtrat ekstrak daging buah tomat di pekatkan dengan rotary evaporator selama 3 jam. Hasil ekstraksi tomat berupa ekstrak kental berwarna coklat

Ekstrak buah tomat (Lycopersicum esculentum) yang didapatkan ditimbang sesuai dosis perlakuan untuk diberikan kepada mencit betina dewasa (Mus muculus) galur Balb/C.

\section{Pemberian Perlakuan Hewan Coba}

Tahap selanjutnya pada penelitian ini adalah tahap pemberian perlakuan ekstrak tomat dengan berbagai dosis pada mencit betina dewasa (Mus musculus) galur Balb/C. Pada awal tahap ini mencit dengan usia 8 bulan ditimbang berat badannya dan dilakukan apusan vagina untuk mengetahui siklus estrusnya. Perlakuan pada hewan coba 24 betina dewasa (Mus musculus) galur Balb/C usia dikelompokkan menjadi 4 kelompok; Kelompok I (kontrol) hanya diberi akuades, kelompok II diberi ekstrak tomat $100 \mathrm{mg} / \mathrm{kg} \mathrm{BB}$, kelompok III diberi ekstrak tomat $150 \mathrm{mg} / \mathrm{kg} \mathrm{BB}$, kelompok IV diberi ekstrak tomat $200 \mathrm{mg} / \mathrm{kg}$ BB diberikan selama 3 hari.

\section{Tekhnik Pengamatan dan Pewarnaan Siklus Estrus}

Pemeriksaan siklus estrus sebelum dan setelah pemebrian ekstrak tomat dilakukan melalui metode apus. Langkah pertama yang dilakukan adalah pengapusan vagina mencit (Mus musculus) menggunakan cotton buds yang telah dibasahi larutan $\mathrm{NaCl}$ 0,9 \% kemudian dimasukkan ke dalam vagina mencit betina dewasa kemudian digosok perlahan. Cotton buds tersebut dioleskan tipis dan searah di atas di atas kaca benda dengan tekhnik smear. Hasil olesan dikeringkan dengan cara dianginanginkan selama kurang lebih 5-10 menit. Hasil olesan yang telah kering diberi pewarna methylen blue kemudian didiamkan selama kurang lebih 30 menit. Preparat dibilas dengan menggunakan aquadest. Kelebihan pewarna dan aquadest 
dibersihkan dengan tisu. Preparat ditutup dengan kaca penutup lalu diamati dengan mikroskop Olympus CX 23 dengan perbesaran 400X. Hasil pengamatan pada mikroskop kemudian di dokumentasikan.

\section{HASIL DAN PEMBAHASAN}

Penelitian mengenai pengaruh tomat terhadap reproduksi mencit betina masih minim. Salah satu hal yang mempengaruhi adalah sifat mencit betina yang cepat stress dibandingkan mencit jantan. Penelitian ini dilakukan dengan tujuan untuk mengetahui pengaruh estrogenik senyawa ekstrak buah tomat (Lycopersicum esculentum) terhadap lama siklus estrus mencit betina (Mus musculus). Penentuan siklus estrus pada penelitian ini dilakukan dengan menggunakan apus vagina/vaginal smear.

Siklus estrus merupakan siklus reproduksi pada hewan mamalia primata maupun mamalia nonprimata [14]. Salah satu hewan yang mengaalami siklus estrus adalah mencit. Dalam satu siklus estrus terjadi perubahan fisiologis dari alat kelamin betina, dapat berupa perubahan sel-sel di bagian vagina mencit. Perubahan ini bersifat sambung menyambung satu sama lain, hingga akhirnya bertemu kembali pada permulaanya. Terdapat 4 fase dalam satu siklus estrus yakni proestrus, estrus, metestrus, dan diestrus.

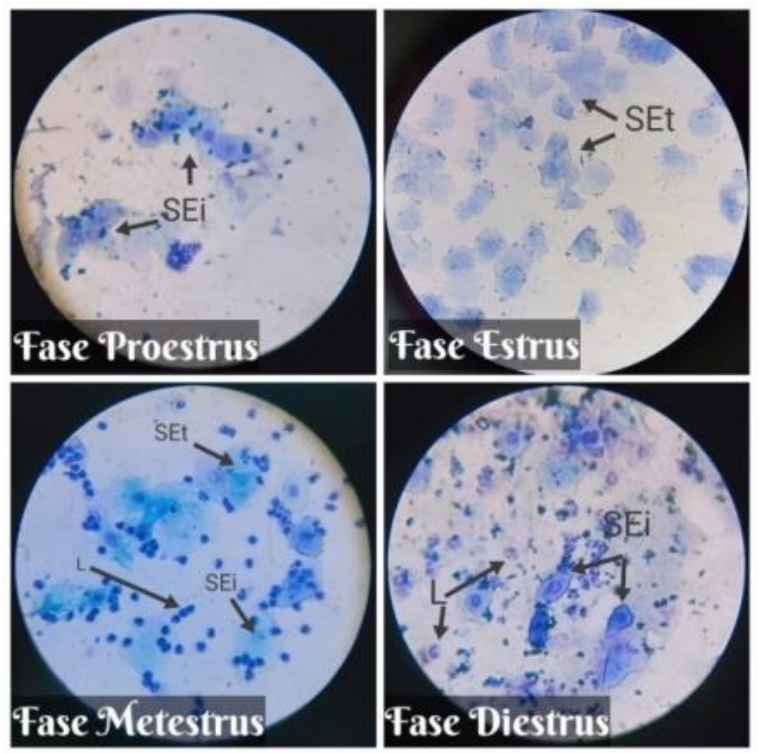

Gambar 1. Fase-Fase dalam Siklus Estrus

Proestrus merupakan fase persiapan. Hasil apus vagina pada fase proestrus sel epitel masih berbentuk bulat [7]. Disamping itu, sel epitel yang tampak adalah sel epitel berinti. Hasil apusan vagina hewan coba pada fase proestrus menunjukkan adanya sel epitel berinti (SEi), tidak ditemukan sel epitel menanduk (SEi) dan leukosit (L). Estrus merupakan fase terpenting dalam siklus. Fase ini ditandai dengan banyaknya sel epitel menanduk (SEt) pada pausan vagina. Pada fase ini pula hewan betina mau menerima pejantan untuk kopulasi. Metestrus merupakan fase yang terjadi segera setelah estrus selesai. Fase ini ditandai dengan adanya sel epitel menanduk (SEt), sel epitel berinti (SEi) dan leukosit (L) pada apusan vagina. Diestrus merupakan fase terlama dalam siklus ini. Fase ini ditandai dengan adanya sel epitel berinti (SEi) dan jumlah leukosit yang banyak pada apusan vagina.

Secara normal, siklus estrus pada mencit berlangsung selama 4 hari [5]. Namun lama siklus tersebut dapat berubah karena beberapa faktor. Terdapat dua faktor yang mempengaruhi yakni faktor intrinsik dan faktor ekstrinsik. Faktor intrinsik adalah faktor dari dalam tubuh mencit yang meliputi umur dan genetik. Faktor ekstrinsik adalah faktor dari luar tubuh mencit yang meliputi fotoperiodisme dan suplai makanan [20].

Tomat merupakan salah satu makanan yang dapat mempengaruhi lama siklus estrus pada mencit. Buah tomat (Solanum lycopersicum L.) memiliki kandungan vitamin $\mathrm{A}$ dan $\mathrm{C}$, serta senyawa anti penyakit yang baik untuk kesehatan terutama likopen. Likopen merupakan zat warna merah yang paling banyak terdapat pada buah tomat [27]. Selain likopen, ada banyak kandungan lain di dalam buah tomat. Shiddiq memaparkan bahwa buah tomat mengandung alkaloid solenoid $(0,007 \%)$, saponin, asam folat, asam malat, asam sitrat, bioflavonoid (termasuk rutin), protein, lemak, gula (glukosa , fruktosa), adenine, trigonelin, kholin, tomatin, mineral seperti $\mathrm{Ca}, \mathrm{Mg}, \mathrm{P}, \mathrm{K}, \mathrm{Na}, \mathrm{Fe}$, sulfur, chlorine, dan vitamin seperti B1, B2, B6, C, E, likopen, niasin, serta histamine. Daunnya mengandung pectin, arbutin, amigladin, dan alkaloid [18].

Hasil penelitian menunjukkan bahwa ada perubahan lama siklus estrus mencit setelah diberikan ekstrak tomat. Pada kelompok kontrol, siklus estrus berlangsung selama 4 hari. Selanjutnya pada kelompok perlakuan 1, perlakuan 2, dan perlakuan 3 siklus estrus berlangsung selama 5 hari. Hal ini dapat dilihat pada Gambar 2.

Pertambahan lama siklus estrus disebabkan oleh perubahan lama fase-fase dalam siklus estrus. Fase proestrus $(\mathrm{P})$ berlangsung kurang dari 1 hari. Fase estrus (E) berlangsung selama 2 hari. Fase Metestrus (M) berlangsung selama satu hari. Fase Diestrus (D) berlangsung selama 1,5 hari. Dari semua fase yang ada, fase yang sangat mempengaruhi pertambahan lama siklus estrus adalah fase estrus. Secara normal, fase estrus berlangsung selama 12 jam [9]. Namun dari hasil yang didapatkan setelah pemberian ekstrak tomat, fase estrus berlangsung selama 2 hari, dengan kata lain melebihi waktu normal. 


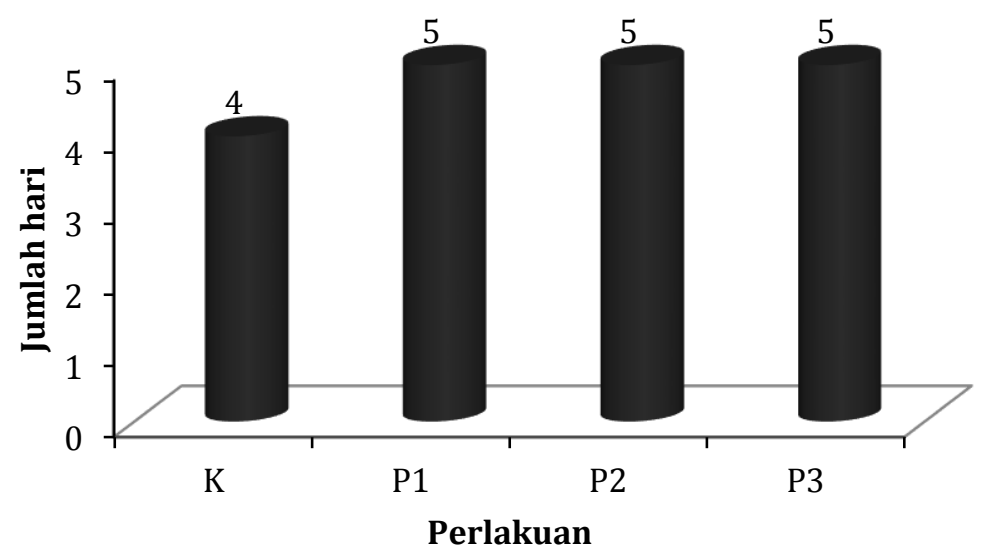

Gambar 2. Perbandingan Lama Siklus Estrus pada Kelompok Kontrol (K) dan Kelompok Perlakuan (P1, P2, P3)

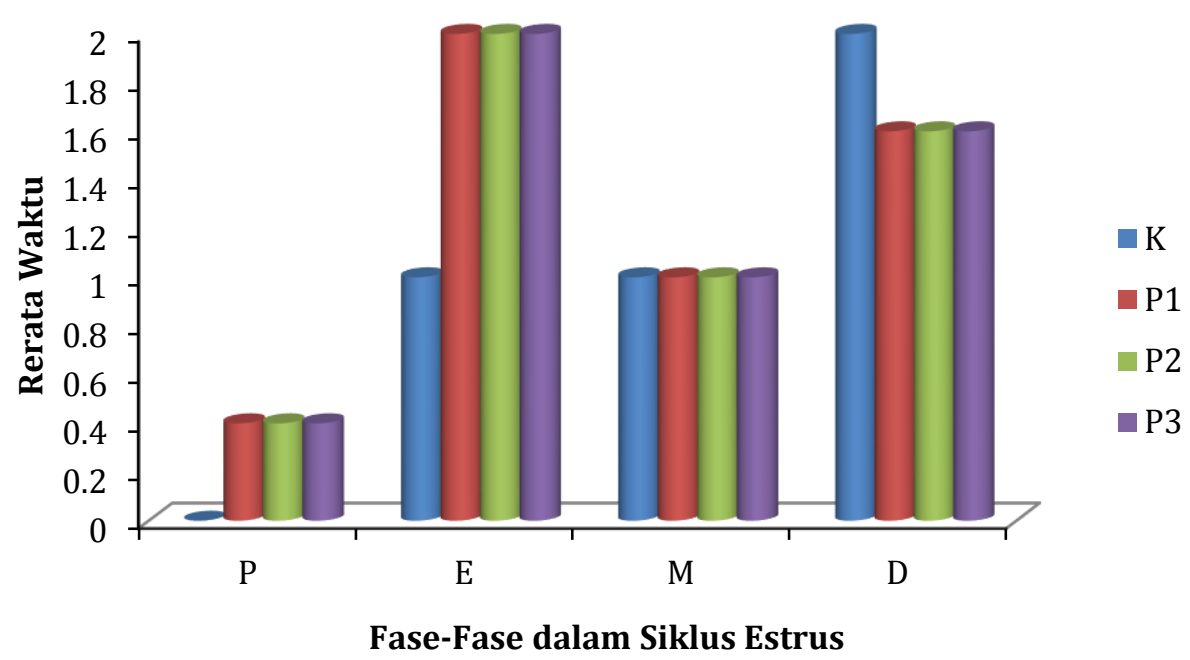

Gambar 3. Perbandingan Setiap Fase dalam Siklus Estrus pada Kelompok Kontrol dan Kelompok Perlakuan.

Ektstrak tomat yang mengandung isoflavonoid diduga menjadi penyebab perubahan lama fase siklus estrus. Mekanisme kerja dari isoflavone sebagai bahan fitoestrogen yang mampu memberikan effek estrogenik pada mencit betina adalah isoflavone yang mirip dengan senyawa $17-\beta$ estradiol akan berikatan dengan reseptor estrogen (ER $\alpha$ ) yang terdapat di membran nukleus, sehingga mengaktivasi elemen respon estrogen disisi dalam membran nukleus. Agar mampu berikatan dengan reseptornya, fitoestrogen harus menembus sel masuk ke dalam sitoplasma membentuk ikatan hormone reseptor pada Estrogen Responsive Element (ERE) yang kemudian bergerak menuju inti sel untuk berikatan dengan DNA, setelah berikatan dengan DNA maka akan terjadi proses transkripsi sel untuk membentuk protein-protein khusus yang diperlukan dalam pembelahan sel. Ketika proses transkripsi sintesis protein, komplek fitoestrogen reseptor estrogen tidak hanya berikatan dengan ERE namun juga berikatan dengan Co-regulator. Co-regulator terdiri dari co-activator yang berfungsi untuk menginduksi terjadinya proses transkripsi gen dari ikatan komplek fitoestrogen reseptor estrogen, sehingga dapat diproduksinya suatu messenger RNA(mRNA) yang mengakibatkan terjadinya sintesis protein sesuai dengan karakteristik hormon, sedangkan corepressor akan bekerja sebaliknya yakni menghambat proses transkripsi gen [9].

\section{KESIMPULAN}

Pemberian ekstrak tomat (Lycopersicum esculentum) dapat meningkatkan siklus estrus pada mencit betina galur Balb/C. Pemberian ekstrak tomat dosis $100 \mathrm{mg} / \mathrm{Kg} \quad$ BBmencit/hari, $150 \mathrm{mg} / \mathrm{BB}$ mencit/hari, dan $200 \mathrm{mg} / \mathrm{BB}$ mencit/hari menujukkan peningkatan siklus estrus selama 1 hari dibandingkan dengan kelompok kontrol tanpa pemberian ekstrak buah tomat (Lycopersicum esculentum). 


\section{DAFTAR PUSTAKA}

[1] Agarwal, S., dan Rao A.V. (2000). Tomato Lycopene and its Role in Human Health and Chronic Diseases. Canadian Medical Association Journal 163(6): 739-44.

[2] Ariyanti, H., \& Apriliana, E. (2016). Pengaruh Fitoestrogen terhadap Gejala Menopause. Jurnal Majority.

[3] Asharii, S. 1995. Holtikultura Aspek Budidaya. Jilid I. Penerbit Universitas Indonesia. Jakarta.

[4] Caseiro, M., Ascenso, A., Costa, A., CreaghFlynn, J., Johnson, M., \& Simões, S. (2020). Lycopene in human health. In LWT. https://doi.org/10.1016/j.lwt.2020.109323.

[5] Darma, V.T., Santoso, M.L., Riyanto. 2017. Pengaruh Ekstrak Daun Pegagan (Centella Asiutica) terhadap Siklus Estrus Mencit (Mus Musculus L) dan Sumbangannya Terhadap Pembelajaran Biologi SMA. Jurnal Pembelajamn Biologi, 4 (I). 77-87.

[6] Hardani, dkk. 2020. Metode Penelitian Kualitatif dan Kuantitatif. Yogyakarta: Penerbit Pustaka Ilmu.

[7] Hayashi, K., D.W. Erikson, S.A. Tilford, B.M. Bany, J.A. Maclean,E.B. Rucker, G.A. Johnson, and T.E. Spencer, 2009. Wnt Genes in the Mouse Uterus: Potential Regulation of Implantation. Biol.Reprod. 88:989-1000.

[8] Huda, N. K. (2017). Pengaruh Ekstrak Sambiloto (Andrographis Paniculata Nees.) Terhadap Siklus Estrus Mencit (Mus musculus L. Swiss Webster). EKSAKTA: Berkala Ilmiah Bidang MIPA. https://doi.org/10.24036/eksakta/vol18iss02/55.

[9] Lusiana, N. 2017. Pengaruh Fitoestrogen Daging Buah Kurma Ruthab (Phoenix Dactylifera L.) terhadap Sinkronisasi Siklus Estrus Mencit (Mus musculus L.). Klorofil, 1(1). 24-31.

[10] Narulita, E., Prihatin, J., Anam, K., \& Oktavia, F. A. R. H. (2017). Perubahan Kadar Estradiol dan Histologi Uterus Mencit (Mus musculus) Betina dengan Induksi Progesteron Sintetik. Biosfera. https://doi.org/10.20884/1.mib.2017.34.3.487.

[11] Nie, Q., Xing, M., Hu, J., Hu, X., Nie, S., \& Xie, M. (2017). Metabolism and health effects of phyto-estrogens. Critical Reviews in Food Science and Nutrition. https://doi.org/10.1080/10408398.2015.107719 4.

[12] Partodiharjo, Soebadi. 1982. Ilmu Reproduksi Hewan. Jakarta: Mutiara

[13] Przybylska, S. (2020). Lycopene - a bioactive carotenoid offering multiple health benefits: a review. In International Journal of Food
Science and Technology. https://doi.org/10.1111/ijfs.14260.

[14] Rugh, Roberts. Ph. D. 1968. The Mouse its Reproduction and Development. Burgess Publishing Company: United State of America.

[15] Saimin, J., Hendarto, H., \& Soetjipto. (2019). The effect of tomato juice in increasing Ki-67 expression and epithelial thickness on the vaginal wall of menopausal rats. Indonesian Biomedical

Journal. https://doi.org/10.18585/inabj.v11i2.517.

[16] Salahuddin, M. S., Safitri, E., Yunita, M. N., Susilowati, S., Hamid, I. S., \& Yudhana, A. (2019). Pengaruh Ekstrak Kedelai (Glycine max) Terhadap Proliferasi Lapisan Endometrium Mencit (Mus musculus). Jurnal Medik Veteriner. https://doi.org/10.20473/jmv.vol2.iss1.2019.4954.

[17] Selamet RN, Sugito and Dasrul. The Effect of Tomato Extract (Lycopersicon esculentum) on The Formation of Athero- Sclerosis in White Rats (Rattus norvegicus) Male. Jurnal natural Saince 2013;13(2): 5-9.

[18] Siddiq, J. 2010. Rahasia, Khasiat dan Manfaat Bumbu Dapur, Rempah- rempah dan Sayuran. Surya Media. Yogyakarta.

[19] Simpson, M.G. 2006. Plant Systematics. Elsevier Inc. Canada.

[20] Sitasiwi, A.J. dan Mardiati, S.M.2016. Efek Antifertilitas Ekstrak Air dari Biji Carica papaya terhadap Keteraturan Siklus Estrus Mencit (Mus musculus L.). Buletin Anatomi dan Fisiologi, 1(1). 68-74.

[21] Sugiritama, I. W., \& Adiputra, I. N. (2019). Potensi Antosianin Dalam Manajemen Menopause. Jurnal Kesehatan Andalas. https://doi.org/10.25077/jka.v8.i1.p158166.2019

[22] Tamilselvan, P., Langeswaran, K., Vijayaprakash, S., kumar, S. G., Revathy, R., \& Balasubramanian, M. P. (2014). Efficiency of lycopene against reproductive and developmental toxicity of Bisphenol A in male Sprague Dawley rats. Biomedicine and Preventive Nutrition. https://doi.org/10.1016/j.bionut.2014.07.008.

[23] Tvrdá, E., Kováčik, A., Tušimová, E., Paál, D., Mackovich, A., Alimov, J., \& Lukáč, N. (2016). Antioxidant efficiency of lycopene on oxidative stress - induced damage in bovine spermatozoa. Journal of Animal Science and Biotechnology. https://doi.org/10.1186/s40104016-0113-9.

[24] Vlaisavljević, S., Colmán Martínez, M., Stojanović, A., Martínez-Huélamo, M., Grung, B., \& Lamuela Raventós, R. M. (2019). Characterisation of bioactive compounds and 
assessment of antioxidant activity of different traditional Lycopersicum esculentum L. varieties: chemometric analysis. International Journal of Food Sciences and Nutrition, 70(7), 813-824.

https://doi.org/10.1080/09637486.2019.158774 2.

[25] Wicaksono, A.W., Trilaksana, I. G. N. B., Laksmi, D. N. D. I. 2013. Pemberian Ekstrak Daun Kemangi (Ocimum basilicum) terhadap Lama Siklus Estrus pada Mencit. Indonesia Medicus Veterinus, 2(4), 369-374.

[26] Widjayanti, Y., \& Prasetya, A. W. (2019). Comparison of the Effectiveness of Tomato (Lycopersicum commune) and Red Melon (Cucumis melo L.) Juice in Increasing Vaginal Wall Thickness of Menopausal Rats Model. Folia Medica Indonesiana. https://doi.org/10.20473/fmi.v55i3.15490

[27] Williams, E. A., Parker, M., Robinson, A., Pitt, S., \& Pacey, A. A. (2020). A randomized placebo-controlled trial to investigate the effect of lactolycopene on semen quality in healthy males. European Journal of Nutrition. https://doi.org/10.1007/s00394-019-02091-5

[28] Winarti, S. 2010. Makanan Fungsional. Yogyakarta: Graha Ilmu.

[29] Wulandari, F. R., Mamfalutfi, T., Dasrul, D., \& Rajuddin, R. (2018). Pengaruh Ekstrak Buah Tomat (Lycopersicum esculentum L.) Terhadap Kadar Hormon Testosteron Tikus Putih (Rattus novergicus L.) Yang Diberi Pakan Tinggi Kolesterol. AVERROUS: Jurnal Kedokteran Dan Kesehatan Malikussaleh. https://doi.org/10.29103/averrous.v2i2.412

[30] Zhu, R., Chen, B., Bai, Y., Miao, T., Rui, L., Zhang, H., Xia, B., Li, Y., Gao, S., Wang, X. D., \& Zhang, D. (2020). Lycopene in protection against obesity and diabetes: A mechanistic review. In Pharmacological Research. https://doi.org/10.1016/j.phrs.2020.104966 